\title{
THE FUTURE OF CLIMATE CHANGE LITIGATION
}

\section{Kim Bouwer}

\section{Abstract}

This article starts the task of expanding the concept of climate change litigation. It argues that a preoccupation with high-profile cases, can divert attention from other important issues litigated within the broader climate change context. The article highlights four key and interrelated considerations that would inform a future conception of climate change litigation. First, climate litigation occurs across scales, and smaller cases at lower levels of governance are as important as more high-profile cases, for myriad reasons. Second, climate change litigation can engage all elements of a good climate response, not just emissions abatement. Third, the extent of private law's potential contribution, tends to be overlooked. Fourth, ignoring 'invisible' climate change cases - or invisible issues within those cases - can result in perilous consequences for climate change policy. Illuminating the implications of all climate cases across scales is fundamental for coherent policy. In addition, this broader conception can support strategic choices.

climate change litigation - climate change policy - mitigation - multilevel governance private law

\section{Introduction}

This paper explores the increasingly important area of climate litigation. Climate litigation has received a considerable amount of scholarly attention. ${ }^{1}$ In this article, I suggest that our understanding of climate change litigation can develop in several ways, and that doing so can support a better and more coherent climate change law and policy. I argue that more attention to four underexplored areas of consideration - which I call 'points of focus' - is necessary. These underexplored areas are as follows.

\footnotetext{
${ }^{1}$ See for instance William CG Burns and Hari M Osofsky (eds), Adjudicating Climate Change (Cambridge University Press 2009); Richard Lord QC and others (eds), Climate Change Liability: Transnational Law and Practice (Cambridge University Press 2011). Also see Lisa Vanhala and Chris Hilson, 'Climate Change Litigation: Symposium Introduction' (2013) 35 Law \& Policy 141 and Elizabeth Fisher and Eloise Scotford, 'Climate Change Adjudication: The Need to Foster Legal Capacity: An Editorial Comment' (2016) 28 JEL 1 and the respective issues. This represents merely a taste of the interesting and thoughtful analysis on this topic.
} 
First, much of the current activity in climate change litigation centres on high-profile cases against national governments or major emitters, seeking increased mitigation ambition or compensation for loss and damage. Significant though these cases are, I argue that it is equally important to look beyond the more obvious climate change cases - particularly those broadly seeking increased mitigation ambition - to assess the role and value of smaller scale, more banal litigation. My second and closely related argument, is that most climate change litigation tends to require improved ambition on abatement (or sometimes adaptation). There is neglected space both in the specifics of mitigation action as reflected in a variety of policy areas, and in the general and specific aspects of other elements of climate change policy.

The third point of focus is the role of private law in climate change cases. With the exception of very high-profile actions I touch on below, the potential of private law is largely overlooked when it comes to climate cases. In particular, I argue that the potential impact of climate cases (in relation to all aspects of a climate change response) is likely to occur both deliberately and inadvertently; private law cases are likely to bear some impact whether or not they are pursued or recognised as climate cases. Private law litigation requires judges to engage in deeply normative processes, for instance in determining what might be reasonable, or the extent to which parties might be required to foresee problems, in relation to specific, contextual situations.

My fourth, related point is that the complexity of the climate problem entails that many climate issues might be 'invisible', even as we work 'in the context of climate change', resulting in the 'climate blind' resolution of disputes. This also means that 'climate change litigation' can happen inadvertently, particularly where this involves small and mundane issues that nevertheless interface with any aspect of domestic climate policy. It is important that we think about litigation 'in the context of' climate change, as well as litigation 'about' climate change, in order to render the invisible visible. Notwithstanding the depth and breadth of the scholarship on climate change litigation, these questions remain underexplored.

\footnotetext{
2 Kim Bouwer, 'Climate Consciousness in Daily Legal Practice' OUP Blog <https://blog.oup.com/authors/kimbouwer/> accessed 11 June 2015.
} 
I do not attempt to 'map' climate change cases, ${ }^{3}$ create categories or draw lines around groups or similar cases. The arguments made are very abstract; where appropriate I draw on examples from the cases or the academic literature to support my arguments. In the next section, and in a few places throughout the paper, I shall refer to 'holy grail' cases. I am using this term throughout to refer to grand, 'aspirational' or newsworthy climate change cases, including but not strictly limited to large scale primary liability cases against big corporations or governments. This is not a term of art, and is certainly not meant to delineate any doctrinal boundaries; but is useful shorthand for a specific kind of case. ${ }^{4}$

The paper also admits to a private law and Anglo-American common law bias. To some extent this reflects the disciplinary proclivities of the author; however this also reflects the genuine need for increased attention on the potential of all private law cases in this context. Despite this, and due to the abstract nature of the considerations raised, I would suggest that many of the assertions made may be generalisable into other disciplinary areas and jurisdictions.

The approach taken is unashamedly instrumental. I argue that paying attention to these impacts of litigation occurring in the context of climate change, is necessary for truly strategic climate change litigation, ${ }^{5}$ and in turn, coherent and effective climate change law and policy. ${ }^{6}$ It has been observed that even with the burgeoning nature of global climate change

\footnotetext{
${ }^{3}$ Recent good mapping exercises include UN Environment and the Sabin Center for Climate Change Law 'The Status of Climate Change Litigation: A Global Review' 2017 and Keely Boom, Julie-Ann Richards and Stephen Leonard, 'Climate Justice: The International Momentum towards Climate Litigation' (2016).

${ }^{4}$ Richard Lord QC, casually used this term in a talk he gave for A4ID at the offices of Clifford Chance in London, on 28 June 2012. David Markell and JB Ruhl, 'An Empirical Assessment of Climate Change in the Courts: A New Jurisprudence or Business as Usual' (2012) 64 Florida Law Review 15 call these the 'sexy' cases, 17. This article aims to recognise the importance of the unsexy cases. In future work, I will illustrate these arguments in more detail in an analysis of specific cases or situations that reflect these the considerations I set out here.

5 Other studies have considered the effects of climate change litigation, in very different ways. See Markell and Ruhl (n 4) who discuss 'pro' and 'anti'. Also Chris Hilson, 'Climate Change Litigation in the UK: An Explanatory Approach (or, Bringing the Grievance Back In)' in F Fracchia and M Occhiena (eds), Climate Change: La Riposta del Diritto (Naples, Editorale Scientifica 2010) and Navraj Singh Ghaleigh, “Six Honest Serving-Men”: Climate Change Litigation as Legal Mobilization and the Utility of Typologies' (2010) 1 Climate Law 31.

6 In several places in this article, I emphasise the importance of 'coherence' in climate change law and policy. Of course, it is also arguable that the demands of climate change will stand to destabilise the law and bring about changes, which in itself could cause incoherence. See Elizabeth Fisher, Eloise Scotford and Emily Barritt, "The Legally Disruptive Nature of Climate Change' (2017) 80 MLR 173, particularly Section 1, and Maria Lee, 'Climate Change Tort' $<$ https://papers.ssrn.com/abstract=2695107 > last accessed 24 July 2017. This is not the space for a full analysis of these seemingly contradictory positions, but I do not find the two inconsistent, or if one would, incoherent. The cited authors assert that the compelling or disruptive nature of climate change litigation stands to change the shape of the law; this is consistent with my requirement that the implications of climate change litigation be consistently dissected for a proper appreciation of these changes and disruptions, whether they tend to support a 'good' response or otherwise.
} 
litigation, the approach taken in jurisdictions outside the US is largely tactical. ${ }^{7}$ The first step towards a strategic approach to litigation, is a proper appreciation of both the immediate implications and radiating effects of all deliberate and focused climate change actions. The second is a full and sustained analysis of the implications of all litigation - including incidental cases brought without activist intent, such as private law cases brought in the pursuit of private interests - but that somehow interfaces with any area of climate change regulation or policy.

This approach is both important and necessary. An adequate response to climate change (involving not just emissions abatement) requires 'all hands on deck', and climate litigation will have some impact, either supporting or undermining these action areas. In many instances, these instrumental effects will occur whether or not the full extent to which the subject matter of the litigation interfaces with climate change, is acknowledged. Not paying sufficient attention to these effects, means ignoring potential frustration of climate change regulation. Understanding climate change as a problem requiring a response on all levels, reminds us that climate change is as much a small scale, local and immediate issue, as it is a global environmental challenge. This encourages a 'climate conscious' approach that emphasises the importance that our conduct, decisions and practice have in relation to the demands of climate change. Thinking in this way about climate litigation can support strategic decisions about where future litigation might occur. Also, focused attention on the implications of small cases that interface with climate policy, can support a proper understanding of where litigation might support or undermine domestic climate change policy. This is important, because to get climate change policy right, it needs to be coherent, and this requires attention to other forms of regulation that might undermine this coherence.

The paper is structured as follows. First, I briefly outline what might be understood by 'climate change litigation.' I touch on the potential for litigation created by the Paris Agreement on climate change. I argue that, rather than obviating any need for citizen action on climate change, this Agreement opens the door to significantly more litigation about climate issues, not less. I explain that properly thinking about the Paris Agreement can facilitate an understanding about where future litigation might occur. I interrogate the continuing role for large scale climate cases aiming to drive increased climate ambition

\footnotetext{
7 Michael B Gerrard, 'Scale and Focus of Climate Litigation Outside of United States' 253 The New York Law Journal. Here, strategic suggests a long term visionary approach, whereas tactical suggests a more immediate focus on particular actions.
} 
amongst states, arguing that these should not be allowed to eclipse the existence of analysis of small cases that interface with various aspects of climate change regulation and policy.

Then I go on to flesh out the four points mentioned above: that climate change litigation happens and should happen across scales; that there is unrecognised potential in all elements of climate change response, as well as in private law; and that these smaller cases (or aspects of them) can be invisible if proper attention is not paid. I propose increased breadth and complexity in the field of climate change litigation, arguing, as above, that this is necessary both to support overt choices about new climate cases, but also to understand the implications of litigation on climate change law and policy.

\section{Climate change litigation}

A wealth of scholarship explores the prospects of and potential for 'climate change litigation'. ${ }^{8}$ Trends and forecasts in the kinds of climate related matters coming before the courts vary across jurisdictions, ${ }^{9}$ and accompanying literature seeks 'to draw thematic or definitional lines ${ }^{10}$ around, impose coherence on ${ }^{11}$ or document ${ }^{12}$ this exploding area of legal action. The worldwide combination of climate cases are a broad and unruly collection. There is no universal or definitive boundary around what might be called 'climate change litigation'. As such, existing scholarship tends to limit the scope of examination to actions that explicitly or overtly relate to climate change; some studies identify only cases where climate change is expressly mentioned in the proceedings. ${ }^{13}$ Other scholars take a more flexible approach. For instance under Hilson's methodology a 'deliberate framing' of a matter as a climate change case - whether expressly in the litigation or subsequently, for instance by the media - would bring it into this wider category. ${ }^{14}$ In this way, actions can be reinterpreted as climate change cases, even if this is not a priority for litigants; in the

\footnotetext{
${ }^{8}$ While much of the scholarship discusses this in general terms, it is possible to make distinctions between 'liability', 'litigation' and 'adjudication', as well as the public and private litigation processes often conflated in the literature. While not terms of art, it seems to be that the term 'liability' approaches litigation outcomes from a purely instrumental perspective; litigation on the other hand seems to encompass a broader perspective including the normative processes involved in the adjudication process itself. Space constraints and the focus of this article do not permit a deeper look at this. A good and interesting discussion of the complex nature of 'adjudication' may be found in Fisher, Scotford and Barritt (n 6) Section 5.

${ }^{9}$ Meredith Wilensky, 'Climate Change in the Courts: An Assessment of Non-U.S. Climate Litigation' [2015] Duke Environmental Law and Policy Forum 131.

10 Elizabeth Fisher, 'Climate Change Litigation, Obsession and Expertise: Reflecting on the Scholarly Response to Massachusetts v. EPA' (2013) 35 Law \& Policy 236; Vanhala and Hilson (n 1).

11 Jacqueline Peel, 'Issues in Climate Change Litigation' (2011) 5 Carbon and Climate Law Review 15.

12 Jolene Lin, 'Climate Change and the Courts' (2012) 32 Legal Studies 35; Wilensky (n 9).

13 Markell and Ruhl (n 4).

14 Hilson (n 5).
} 
absence of such reinterpretations, such cases would be 'invisible'. I shall return to this point below. $^{15}$

Until recently, significant high profile successes in climate change litigation centred on public law challenges. Public litigation has more immediate potential to strong-arm regulators into action. Aggressive and strategic ${ }^{16}$ administrative law challenges from both 'sides' have unarguably shaped the US domestic regulation relating to the production and consumption of energy. ${ }^{17}$ Echoing this approach, Fisher identifies response to institutional failure as one of three key factors driving climate litigation. ${ }^{18}$ The importance of litigation goes to acknowledge the importance and potential of the conduct of non-state parties, including corporations, to stimulate action or at least challenge government failures in this regard.

Climate change litigation in the United Kingdom has a fairly diverse profile in terms of subject matter, and is largely constituted by public law challenges, and a few criminal matters. The substance of the challenges include 'emissions sources' such as airports and incinerators, a few planning decisions relating to urban expansion, disputes concerning allocation under the EU ETS and some disparate human rights actions, as well as criminal proceedings. ${ }^{19}$ The majority are public law challenges to a grant or refusal of planning permission in relation to renewable energy projects, mainly wind farms. ${ }^{20}$ Of course, siting is important, and there are many very legitimate reasons why permission for new projects might be refused; however where planning is refused, this would undermine one more step on the transition to a low carbon pathway. ${ }^{21}$

It was concluded fairly early on that the duties under the Climate Change Act 2008, if unfulfilled, did not create scope for a grand challenge, ${ }^{22}$ but made a normative contribution,

\footnotetext{
15 Section 3.4.

16 Gerrard (n 7).

17 Hari M Osofsky, 'The Role of Climate Change Litigation in Establishing the Scale of Energy Regulation' (2011) 101 Annals of the Association of American Geographers 775. Not only are the outcomes of challenges to regulation (or failures to regulate) significant, but repeat strategic litigation has forced energy regulation to different levels of governance.

${ }^{18}$ Fisher (n 10). This article discusses Massachusetts v EPA 549 US 497 (2007).

19 See http://climatecasechart.com/non-us-jurisdiction/united-kingdom/ (last accessed 20 July 2017) and also Hilson (n 5).

${ }^{20}$ See Wilensky (n 9) Section 3.4.4.2. Natalie Jones, 'Wind Energy and Adverse Visual-Impact Litigation: A Balance of Global and Local Interests?' [2016] Climate Law 336 records 68 such cases. As Jones's title indicates, many were litigated due to concerns about aesthetics, and as such certainly many of these cases would be excluded from studies employing narrower criteria to determine what constitutes climate litigation.

21 Jones (n 20).

22 In essence, questions arose as to whether the duties under section 1 and 4 are unusual and enforceable. J. F. Garner, Paul Street, Charles Smith, Ian Doolittle, and DJ Harris, Garner's Environmental Law (Revised edition. Butterworths Law 1991) 5B.23 suggest that it is enforceable by means of judicial review. Colin T Reid, 'A New Sort of Duty?: The Significance of "Outcome" Duties in the Climate Change and Child Poverty Acts' [2012] Public Law 749 asserts that
} 
representing a 'socially transformative broader goal'. ${ }^{23}$ Having said that, there clearly are some talking points concerning the political will and capacity to design and implement the policies necessary to fulfil these broader duties. ${ }^{24}$ Recent years have been marked by incoherent and inconsistent policy in energy and climate change ${ }^{25}$ and inexplicable delays both in the publication of a new emissions reduction plan or any policies to give effect to any plan. ${ }^{26}$ There are suggestions of a growing appetite, in the UK, for challenges to be brought on this basis. At the time of writing, early rumblings would suggest that this is far from quelled by the publication of the long overdue Clean Growth Strategy. I shall return to the issue of policy implementation later in the paper.

\subsection{Search for the 'Holy Grail'}

The proliferation of climate cases notwithstanding, no discussion of climate change litigation is complete without reference to the 'holy grail' climate change cases. ${ }^{27}$ As I explain above, I am not seeking to delineate categories of cases, but this term is useful shorthand for a specific kind of case: a high-profile (predominantly) private law action against a group of major emitters or (latterly) nation states, seeking damages for climate harms. This was how climate change litigation was conceptualised when scholarly attention first turned to the possibility of climate litigation. ${ }^{28}$ Because of the doctrinal problems anticipated with these cases (including but not limited to, foreseeability and proof of causation), they could be seen as reflecting the ultimate aspiration for climate litigators. ${ }^{29}$ And indeed, until fairly recently,

\footnotetext{
the section 1 duty is of a particular nature that motivates for enforcement in relation to outcome, even as this seems implausible.

23 Aileen McHarg, 'Climate Change Constitutionalism? Lessons from the United Kingdom' (2011) 2 Climate Law 469. 479

24 Matthew Lockwood, 'The Political Sustainability of Climate Policy: The Case of the UK Climate Change Act' (2013)

23 Global Environmental Change 1339. At 1341 Lockwood notes that '...research ...has opened up the implementation process, recognising that policy continues to be defined during the process of implementation, and that implementation is just as much a contested and political process as adoption.'

25 ClientEarth, 'Mind the Gap: Reviving the Climate Change Act' (2016) Section 3. The report explains that despite a formal compliance with its own carbon budgets, the UK government has failed to adhere to its own emissions reduction policy (Department of Energy and Climate Change, 'The Carbon Plan' (2011)), and also paid little attention to the concerns raised annually by its own advisory body, which insists that in many instances purported reductions do not reflect a sustainable low carbon pathway.

${ }^{26}$ ClientEarth (n 25) Section 4.

27 What follows shall be an extremely light overview of these important and interesting cases. There is much to say but my comments here are largely to provide context for the remainder of the paper, as I shall caution against too much attention on these kinds of cases. I explore the implications of these cases in more depth in other work in progress.

${ }^{28}$ See Eduardo M Penalver, 'Acts of God or Toxic Torts - Applying Tort Principles to the Problem of Climate Change' (1998) 38 Natural Resources Journal 563 and David A Grossman, 'Warming up to a Not-So-Radical Idea: Tort-Based Climate Change Litigation' (2003) 28 Columbia Journal of Environmental Law 1.

${ }^{29}$ For example: David Hunter and James Salzman, 'Negligence in the Air: The Duty of Care in Climate Change Litigation' [2007] University of Pennsylvania Law Review 1741; Douglas Kysar, 'What Climate Change Can Do About Tort Law' (2011) 41 Environmental Law 1- a lengthy list of articles discussing this issue is found at Kysar's note 3.
} 
they seemed doomed to remain aspirational. The generation of cases was brought in the United States in response to incidents or situations thought to be caused or contributed to by climate change, ${ }^{30}$ such as Hurricane Katrina, ${ }^{31}$ or progressive erosion and increased flood risk. ${ }^{32}$ To some extent expectations were met, in that all the cases failed, although not necessarily due to the doctrinal vulnerabilities explored by scholars.

New strategies emerged. Again, while space (and this article's purpose) does not permit a deep doctrinal analysis of these cases, it is worth making a few observations as such cases will probably exemplify and dominate attention on 'climate change litigation' in the future. The newer generation cases reflect a thoughtful and deeply strategic response to the difficulties encountered by the claimants in the previous cases. Existing in three overlapping waves - the tort wave, the public trust wave and the 'carbon majors' wave - the new holy grail cases tend to be born from specific theoretical manifestos which seek to pursue climate litigation for a specific instrumental purpose - to force national governments to take more stringent action towards the reduction of their greenhouse gas emissions, and/or to force payments for climate change loss and damage based on historical responsibility.

The first wave arose from concerns about the global energy system and frustration with the prevailing slow progress in the international climate change regime. ${ }^{33}$ It was initiated with an unexpected triumph in the Hague District Court in the matter of Urgenda Foundation $v$ the Kingdom of the Netherlands. ${ }^{34}$ This action re-enlivened interest in the potential of large-scale private law climate change litigation, ${ }^{35}$ although it is likely that similar claims would raise problems in an Anglo-American court. ${ }^{36}$ The decision admits of some jurisdictional and doctrinal vulnerabilities, ${ }^{37}$ and has been appealed.

Also Jutta Brunnee and others, 'Overview of Legal Issues Relevant to Climate Change' in Richard Lord QC and others (eds), Climate Change Liability: Transnational Law and Practice (Cambridge University Press 2011).

30 I am following the generational approach used by Randall Abate, 'Atmospheric Trust Litigation in the United State: Pipe Dream or Pipeline to Justice for Future Generations?' in Randall Abate (ed), Climate Justice (Environmental Law Institute, Washington DC, 2016).

31 Comer v. Murphy Oil USA, 585 F.3d 855, 880 (5th Cir. 2009); Comer v Murphy Oil USA, Inc 839 F. Supp. 2d 849, 85562 (S.D. Miss. 2012)

32 Native Village of Kivalina v. ExxonMobile Corp 9th Cir., No. 09-17490 (September 21, 2012). Luciano Butti, 'The Tortuous Road to Liability: A Critical Survey on Climate Change Litigation in Europe and North America' (2011) 12 Sustainable Dev. L. \& Pol'y 32 provides a good summary of these cases.

33 Roger Cox, Revolution Justified (Planet Prosperity Foundation 2012).

${ }^{34}$ ECLI:NL:RBDHA:2015:7196. KJ de Graaf and JF Jans, 'The Urgenda Decision: Netherlands Liable for Role in Causing Dangerous Global Climate Change' (2015) 27 Journal of Environmental Law 517.

35 Leghari $v$ Federation of Pakistan (W.P. No 25501/2015)

${ }^{36}$ Josephine van Zeben, 'Establishing a Governmental Duty of Care for Climate Change Mitigation: Will Urgenda Turn the Tide?' (2015) 4 Transnational Environmental Law 339349 - 352 - although R Henry Weaver and Douglas A Kysar, 'Courting Disaster: Climate Change and the Adjudication of Catastrophe'

$<$ https://papers.ssrn.com/abstract=2965084> accessed 21 July 2017, $42-53$ seem to find more similarities. Also see Giedre Kaminskaite-Salters, 'Climate Change Litigation in the UK: It's Feasibility and Prospects' in Michael Faure 
The second wave is made up of 'public trust' cases. These 'civil rights' cases ${ }^{38}$ are rooted in academic work establishing the concept of an 'atmospheric trust' ${ }^{39}$ and are part of a 'coordinated litigation campaign', ${ }^{40}$ Actions have been brought in several US states ${ }^{41}$ and actions are contemplated in other jurisdictions. ${ }^{42}$ The claimants are predominantly children, seeking relief for their government's failure to protect their 'atmospheric trust', and have produced evidence of loss and harm to their health and enjoyment of life. The most highprofile Juliana decision has already survived the kinds of jurisdictional challenges that brought an end to 'holy grail' cases of the previous decade. It will proceed to a full hearing in February 2018. While there are no final decisions as yet, these actions have already made significant steps forward in terms of a citizen challenge to government for a failure to protect citizen's interests.

The still-forming third 'wave', very much in its nascent stages, is constituted by 'carbon majors' litigation. As before, this new wave is underpinned by scholarly analysis which has sought to assign responsibility for climate change to major emitters, based on progressive scientific work on attribution, ${ }^{43}$ and a philosophical interpretation of the implications of that work. ${ }^{44}$ This wave of litigation has already given rise to human rights complaints, and may mark a return to major climate cases against entities identified as responsible for a large amount of emissions. ${ }^{45}$ A first set of proceedings has been issued. ${ }^{46}$

and Marjan Peeters (eds), Climate Change Liability (Edward Elgar Publishing Limited 2011) and Silke Goldberg and Richard Lord QC, 'England' in Richard Lord QC and others (eds), Climate Change Liability: Transnational Law and Practice (Cambridge University Press 2011), 457 - 475.

37 de Graaf and Jans (n 34), 523 - 526.

38 Juliana v. United States, Case No. 6:15-cv-01517-TC, 2016 WL 6661146 (D. Or. Nov. 10, 2016) [1].

39 This wave is underpinned by theoretical writing about the significance of the 'public trust' as a tool of natural resources governance: Mary Christina Wood, Nature's Trust: Environmental Law for a New Ecological Age (Cambridge University Press 2014) and is informed by the scientific work of James Hansen, who is also a party to the Juliana proceedings. See James Hansen and others, 'Assessing "Dangerous Climate Change": Required Reduction of Carbon Emissions to Protect Young People, Future Generations and Nature' (2013) 8 PLoS ONE e81648.

40 Juliana (n38) [57].

${ }^{41}$ See https://www.ourchildrenstrust.org/us/federal-lawsuit/.

42 https://www.ourchildrenstrust.org/global-legal-actions. There are questions as to whether English atmospheric trust litigation would achieve success: see Bradley Freedman and Emily Shirley, 'England and the Public Trust Doctrine' (2014) 8 Journal of Planning \& Environment Law 839 or less optimistically: Goldberg and Lord QC (n 36), 478. See however Juliana (n38) [24].

43 Richard Heede, 'Tracing Anthropogenic Carbon Dioxide and Methane Emissions to Fossil Fuel and Cement Producers, 1854-2010' (2014) 122 Climatic Change 229; B Ekwurzel and others, 'The Rise in Global Atmospheric CO2, Surface Temperature, and Sea Level from Emissions Traced to Major Carbon Producers' (2017) 144 Climatic Change 579.

44 Peter C Frumhoff, Richard Heede and Naomi Oreskes, 'The Climate Responsibilities of Industrial Carbon Producers' (2015) 132 Climatic Change 157; Henry Shue, 'Responsible for What? Carbon Producer C02 Contributions and the Energy Transition' (2017) 144 Climatic Change 591.

45 UN Environment (n 3), 21 - 22.

${ }^{46}$ Laura Paddison 'Exxon, Shell and other carbon producers sued for sea level rises in California' The Guardian Wednesday 26 July 2017. The complaints are available here: https://www.sheredling.com/press-room/. 
All these cases will have broad implications that extend beyond the discrete litigation. ${ }^{47}$ However, the purpose of this paper is not to explore these implications; rather it is to emphasise that a preoccupation with 'holy grail' cases can obscure both the instrumental potential, and possible implications, of much less visible forms of litigation about climate change. First, however, it is necessary to make a few comments as to why there remains any space for litigation, given recent progress in the international governance of climate change.

\subsection{The Paris Agreement and New Space for Litigation}

I conclude this section by making some comments on the continued need for climate change litigation, subsequent to the Paris Agreement of 2015. This new hopeful agreement on climate change establishes a basis for global commitments on climate action, with review processes to facilitate accountability and increased ambition. The ambition and supportive architecture in the Agreement ${ }^{48}$ could justify an argument that - other than in certain rogue states - there is a no longer a need for litigation around climate change. Now, part of my motivation in writing this article is to suggest that a preoccupation with 'holy grail' type cases is misconceived, not that they serve no purpose at all. These cases are attractive to litigators and of course, they do have their place. But an aspiration to pursue only these kinds of cases is a little limited given the scope offered. I argue elsewhere, ${ }^{49}$ that the continued relevance of the holy grail cases lies in their capacity to serve a normative and compliance purpose, as well as maintaining awareness of the 'ambition gap' represented by the Paris commitments. But the 'holy grail' cases are simply the tip of the iceberg in terms of the ongoing and complex ways in which climate litigation can continue to contribute, as I shall explore in the next section.

If anything, the Paris Agreement creates new scope for climate litigation. It also creates a necessity for more analysis and reflection on the implications of existing climate change litigation, including 'inadvertent' climate change litigation, brought for other purposes. PostParis, all states have clear and differentiated mitigation commitments and are subject to accountability processes for these. ${ }^{50}$ Parties will submit nationally determined contributions,

\footnotetext{
${ }^{47}$ In further work in progress I examine the impacts of large-scale climate cases such as these.

48 Paris Agreement (FCCC/CP/2015/L9/Rev1).

49 In the work-in-progress referred to in $\mathrm{n} 47$ above.

50 e.g. Lavanya Rajamani, 'Ambition And Differentiation in the 2015 Paris Agreement: Interpretative Possibilities and Underlying Politics' (2016) 65 International \& Comparative Law Quarterly 493. I appreciate that all aspects of my statement are a gross oversimplification of the Agreement.
} 
which are subject to a review and assessment process, ${ }^{51}$ and are to be increased over time. ${ }^{52}$ Parties are required to 'pursue domestic mitigation measures' ${ }^{53}$ which would include national legislation and policy for mitigation. ${ }^{54}$ In addition, parties are required to 'undertake and communicate ambitious efforts' 55 in relation to mitigation, adaptation, finance, technology transfer, capacity building, and transparency. ${ }^{56}$ As such, the success of the global response to climate change depends very much on effective and coherent climate change policy in each member state.

These elements of national policy stand to be tested by litigation in the domestic courts; specifically, this is not about litigants seeking to enforce the Paris Agreement domestically, but testing domestic policies enacted to give effect to international commitments. As Lord Carnwath explains: 'Post Paris, the importance of [litigation] is to show the potential force of NDCs and domestic measures, even without limits binding in international law. National legislatures bear the primary responsibility to give legal effect to the commitments undertaken by states under the Paris Agreement. However, the courts will also have an important role in holding their governments to account, and, so far as possible within the constraints of their individual legal systems, in ensuring that those commitments are given practical and enforceable effect. ${ }^{57}$ In essence, this is not about seeking to establish or enforce temperature or emissions reductions limits, with focus on climate ambition overall, ${ }^{58}$ this is about testing and giving effect to very specific, potentially unglamorous areas of climate change policy and regulation.

On the one hand, civil actions seeking to compel increased climate mitigation ambition from governments may not carry the moral force of a large group action like Urgenda. ${ }^{59}$ In any event, wanting another Urgenda reveals a lack of imagination in terms of the true potential private litigation has, to stimulate climate action. On the other hand, there are talking points as to whether a 'well below 2 degree ${ }^{60}$ target is achievable or indeed desirable. ${ }^{61}$ There is a

\footnotetext{
51 Rajamani (n 50), $496-502$.

52 Rajamani (n 50) $502-505$.

53 Article 4(2)

54 Daniel Bodansky, 'The Paris Climate Change Agreement: A New Hope?' (2016) 110 American Journal of International Law 288 IV A.

${ }_{55}$ Article 3

56 'As nationally determined contributions to the global response to climate change, all Parties are to undertake and communicate ambitious efforts as defined in Articles 4, 7, 9, 10, 11 and 13, with a view to achieving the purpose of this Agreement as set out in Article 2....'

57 Lord Robert Carnwath JSC, 'Climate Change Adjudication after Paris: A Reflection' (2016) 28 JEL 5.

58 I am not suggesting that no scope remains for this kind of action; I am cautioning against an obsession with this kind of action obscuring the potential of all other kinds of actions.

59 Other than, of course, parties that had shown bad faith in relation to their commitments.

60 Article 2(a) Paris Agreement (n 48).
} 
deficit in parties' nationally determined contributions, ${ }^{62}$ but also possibly in coherent and effective national policies that might support their achievement. I would argue that the danger of pursuing such cases is that it achieves little in terms of policy improvement, and distracts attention and resources from other policy areas, where litigation could have a more significant effect in terms of improving the climate change response.

\section{Scale, Elements and Invisibility in Future Climate Litigation}

In the previous section I suggested that the rejuvenated climate change regime has not rendered climate litigation otiose. If anything, it both creates new possibilities for, and illuminates areas of climate change response where the potential for regulatory challenges, including litigation, are underutilised. I also suggested that, notwithstanding their value, a preoccupation with 'holy grail' cases represents many opportunities missed. I alluded to various issues that have potential to shape and redefine climate change litigation. In this section, I highlight these four points of focus in a very abstract way. I am not suggesting that these would occur simultaneously or be features of every climate change case. These are simply neglected areas of focus that I believe require more attention.

First, I shall explain the importance of scaling down. This includes both understanding that global climate change must now be dealt with at national level, but also that attention to small and mundane domestic and local disputes can make a contribution to coherent national climate policy. Second, I challenge the notion that climate change litigation stands only to drive or undermine ambition on mitigation or adaption policy. The elements of action reflected in the new agreement, if anything, illuminate the breadth of issues and disputes that interface with any aspect of climate policy. Third, I argue that, with the exception of the 'holy grail' litigation, private law tends to be overlooked as far as its potential contribution to climate change litigation is concerned. I suggest that reminding ourselves of the instrumental potential of private law can resuscitate this neglected area. Fourth, I look back to the possibilities that climate change, or issues relevant to it, might not be identified as such, even when the very dispute is situated within the context of climate change. I therefore emphasise the importance of recognising what might be 'invisible' climate change

61 Hansen and others (n 39); UNEP, 'The Emissions Gap Report 2015: A UNEP Synthesis Report' (2015); Joeri Rogelj and others, 'Paris Agreement Climate Proposals Need a Boost to Keep Warming Well below $2{ }^{\circ} \mathrm{C}^{\prime}$ (2016) 534 Nature 631.

62 Rogelj and others (n 61). 
issues in private litigation; I suggest a broader understanding of when private law disputes might be considered climate change litigation.

My core point, is that in order to achieve effective climate action, including the substantial decarbonisation ${ }^{63}$ required to fulfil the promises of Paris, coherent climate change policy is required. This requires consistency but also that one element of climate response not frustrate another. Because litigation in this area - including private litigation - stands to support or undermine these policies, it is important that this contribution be acknowledged. In addition, of course, this might provide fertile ground for strategic litigation, or improved strategic approaches within existing litigation.

\subsection{Scales of Governance}

The hybrid post-Paris regime combines 'bottom-up' party autonomy in national contributions with 'top down' transparency, compliance and accountability. ${ }^{64}$ The conception of climate change as (solely) an international problem with (solely) international solutions, is outdated, as is the understanding that there is a single global panacea for the climate problem. ${ }^{65}$ Good responses to climate change need to reflect a variety of regulatory forms across levels ${ }^{66}$ or scales of governance. ${ }^{67}$ These need to be coherent. Of course, it could be argued that the distinction between scale and level is semantic, and that this variation in characterisations does not matter. I find Osofsky's analysis based on scale the most compelling, as the predetermined rigidity inherent in complex levels of governance overlooks the fluid interactions between them. Treating jurisdictional levels as inert ignores what is frequently happening in the interpretation or adjudication of legal issues. This demands that we resist the temptation to categorise or assign cases or legal issues to levels of governance: domestic, regional, international, because the potential of these cases could work across scales of governance. ${ }^{68}$

\footnotetext{
${ }^{63}$ Chris Bataille and others, 'The Need for National Deep Decarbonization Pathways for Effective Climate Policy' (2016) 16 Climate Policy S7.

64 Rajamani (n 50), 502 and generally.

65 The 'silver bullet' of Gwyn Prins and Steve Rayner, 'The Wrong Trousers: Radically Rethinking Climate Policy' (2007).

${ }^{66}$ Jacqueline Peel, Lee Godden and Rodney J Keenan, 'Climate Change Law in an Era of Multi-Level Governance' (2012) 1 Transnational Environmental Law 245; Joanne Scott, 'The Multi-Level Governance of Climate Change' in Paul Craig and Grainne De Burca (eds), The Evolution of EU Law (OUP 2012).

67 Hari Osofsky, 'Scales of Law: Rethinking Climate Change Governance' (University of Oregon 2013)

<https://scholarsbank.uoregon.edu/xmlui/bitstream/handle/1794/13297/Osofsky_oregon_0171A_10730.pdf?sequ ence $=1>$.

68 Osofsky, 'The Role of Climate Change Litigation in Establishing the Scale of Energy Regulation' (n 17).
} 
According to Osofsky, the literature on scale supports an understanding of the regulatory complexity surrounding the climate change problem in three different ways. The first is that it illuminates the need for a pluralistic or 'polycentric' governance structure, which needs to be responsive to the complexities across different levels. This also demands a hybrid approach to governance. ${ }^{69}$ The second way in which a conception of scale contributes to our understanding of effective climate change governance, is that it demands an inclusion of the smaller scales in relation to the globalised approach taken to climate change mitigation. I would argue that this is less a requirement for permission for these scales to interact with higher levels of governance, and more an imperative that the impact of their multiple actors be recognised, as they will have an impact whether this is acknowledged, or not. As Osofsky explains: "[E]ach lost opportunity to limit emissions and respond constructively to this problem increases the risks. ${ }^{70}$

Third, effective climate governance requires a range of tools and agencies. ${ }^{71}$ In as much as these concepts can incorporate litigation as an instrumental process, and recognise the agency of both courts and litigant-citizens, this requires a recognition of the intended and inadvertent impacts of litigation on climate governance areas. '...[C]omplex multi-level contestation, such as in litigation, forms part of climate change regulation. ${ }^{, 72}$ Thus, dynamic and multi-agency approaches to the governance of climate change can be interpreted as an acknowledgement of the necessity of multiscalar responses to climate change. ${ }^{73}$

However characterised, we are to understand that effective climate governance occurs across scales of governance simultaneously: this is not a choice between 'top-down' or 'bottom-up' approaches. If anything, this exposes that the concept of a governance system that is unidirectional and vested in a solitary system, will prove to be woefully inadequate. Rather, effective climate governance requires the simultaneous and coherent operation of multiple governance forms. This also requires an appreciation of the interactions between scales of governance and the interplay between them. In essence, much of the structural criticism of the 'old' regime stressed the futility of relying on one measure - such as imposed international emissions reduction pledges - to achieve the broad change necessary to solve

\footnotetext{
69 Osofsky, 'Scales of Law: Rethinking Climate Change Governance' (n 67), 39 - 43.

70 Ibid 54.

71 See Elinor Ostrom, 'Polycentric Systems for Coping with Collective Action and Global Environmental Change'

(2010) 20 Global Environmental Change 550.

72 Osofsky, 'Scales of Law: Rethinking Climate Change Governance' (n 67), 48.

${ }^{73}$ Hari M Osofsky, 'Adjudicating Climate Change across Scales' in William CG Burns and Hari M Osofsky (eds),

Adjudicating Climate Change (1st edn, Cambridge University Press 2009), or any of the case studies in Osofsky, 'Scales of Law: Rethinking Climate Change Governance' (n 67).
} 
the climate problem. Effective climate governance would happen simultaneously at different scales of governance, ${ }^{74}$ and using a variety of regulatory measures. ${ }^{75}$ This approach also demands an inclusion of the smaller scales in relation to the globalised approach taken to climate change mitigation. This may seem like a very obvious point, but climate change continues to be 'pushed out' as an issue of national policy in local decisions. ${ }^{76}$

As I discuss above, this is of particular relevance when the regulatory implications of litigation are taken into account. The crux of this is, stated very simply, that the small cases matter. The heroism of large-scale group actions does not justify overlooking the impact of adjudication taking place at smaller scales of governance that have potential to contribute to or undermine a good climate response, or, indeed to do both. Less high profile litigation in the climate context certainly has some impact on the behaviour and decisions of governments or private parties. ${ }^{77}$ To some extent, because of the cumulative nature of the climate problem, a climate adverse resolution of any dispute - including a failure to support emissions reduction, however minimal - represents one more missed opportunity to reduce the density of atmospheric greenhouse gases that will contribute to dangerous climate change. ${ }^{78}$ At the risk of overstating this point, I reiterate that it would be foolish to dismiss the climate impact of small and less visible cases, as negligible. ${ }^{79}$ While it is correct that in such cases, taken individually, the implications for the reduction of global emissions may well be negligible, the combined implications of many such cases, would not be.

\subsection{Elements of Action}

\footnotetext{
74 Peel, Godden and Keenan (n 66); Scott (n 66). See further my discussion of scale below.

75 The 'buckshot' of Prins and Rayner (n 65).

76 See Frackman v Secretary of State CLG [2017] EWHC 808 (appeal decision awaited), where an application for statutory review of a grant of planning permission. The court approved a finding that 'fracking' was consistent with national energy and climate change targets, despite a lack of clear indication as to how the conditions the Committee on Climate Change required for this to be the case, would be met. The court also refused to find that any assessment of future emissions from either of the potential 'fracking' sites was necessary. The quotation is from Estelle Dehon, the second claimant's barrister, at 'Fracking: Regulation, Risk and Responsibility' an event co-hosted by UK Environmental Law Association and the Society of Legal Scholars, in Manchester on 1 November 2017.

77 Brian J Preston, 'The Influence of Climate Change Litigation on Governments and the Private Sector' (2011) 2 Climate Law 485 - including private litigation.

78 This point is well made by Osofsky, 'Scales of Law: Rethinking Climate Change Governance' (n 67), 'Climate change is an individual, local, state, national, regional and international problem. Because carbon is so deeply embedded in the global economy and its impacts manifest in specific ways in different places, emissions and impacts occur at multiple levels simultaneously....[T]he valorisation of the 'international' in the climate change debate... serves as an impediment to such cross-cutting efforts. If regulatory strategies focus only on top-down, international-level approaches grounded in nation-state consent, we will miss opportunities for much needed innovation and emissions reduction.', 48.

${ }^{79}$ As explained in the introduction, many of the assertions made are made in abstract way. Space and the intent of the paper does not permit much doctrinal elaboration from existing case law, or even less, empirical evaluation of the points made. My intention, in this article, is to explain the points of focus that I believe should inform a broader understanding of climate change litigation. In future work, already in progress, I shall illustrate these arguments with an analysis of existing case-law.
} 
The new, or rejuvenated, climate regime includes all nations and aims to address mitigation, adaptation, finance, technology transfer, capacity building, transparency, and loss and damage. All of these elements of action - as priorities of The Paris Agreement - are fundamental for its functioning. ${ }^{80}$ And of course technology transfer and finance simultaneously provide enablement and support for the achievement of the other areas of response. All these elements should be reflected in the national, regional and local policy and regulation, and individual actions, that aim to support ongoing climate action. ${ }^{81}$ Now of course, earlier I suggested that an expanding role exists for climate change litigation in a post-Paris world. I argued that, far from rendering citizen's recourse to courts unnecessary, the 'new' regime opens up space and scope for newer and more specific tranches of litigation to challenge the domestic processes designed to achieve the state's Paris goals. This also opens up possibilities for a deeper and more refined understanding of the implications of cases that would be brought anyway. Rather than just seeking to set broad mitigation goals, this means testing specific policies and areas of regulation.

As such, I would suggest that a greater recognition of these multiple elements of action, and their inter-relationship with one another, is necessary in future climate litigation. Yet at present, most climate change litigation - including 'holy grail' actions - are focused on the abatement or emissions reduction aspects of mitigation. ${ }^{82}$ (An exception is the public trust wave of litigation, in which the plaintiffs seek both sharp emissions reductions (abatement) as well as reforestation and improved agricultural practices to improve 'drawdown' (other mitigation measures). $)^{83}$ Of course, this is not to say that emissions reduction is not needed. However, in as much as an obsession with the grand scale is an outmoded response to climate change, so is an obsession with abatement. This overwhelming focus on direct abatement crowds out other aspects of the climate change response, including smaller and more specific issues that enable and support both the abatement of emissions, and other mitigation specific issues. In short, for litigation to give effect to mitigation goals, it would focus not only on direct abatement, but also all other aspects of the mitigation response,

80 With one exception, these reflect the much debated pillars of the Bali Action Plan - see Lavanya Rajamani, 'The Durban Platform for Enhanced Action and the Future of the Climate Regime' (2012) 61 International \& Comparative Law Quarterly 501.

81 I appreciate that it might seem unrealistic, to suggest that, for instance, local actions could have any impact on international transfers of technology, or flows of finance. I do not have space to explore the minutiae of how this might be possible, in this article, but I do make some comments about this, below.

82 Wilensky (n 9).

83 See Michael C Blumm and Mary Christina Wood, “No Ordinary Lawsuit": Climate Change, Due Process, and the Public Trust Doctrine' (2017) 67 American University Law Review (forthcoming) 14 - 15 and Hansen and others (n 39). Drawdown refers to processes by 'sinks', including vegetation and soils, which remove atmospheric CO2 - see Hansen and others (n 39) at 10. 
including the minutiae of climate change mitigation policy. For instance, in the UK context, litigation about the preservation of green spaces, such as village greens, is as much climate change litigation as are challenges related to wind farms. This is precisely because of their potential to contribute to 'drawdown', thus each making a small contribution to mitigation goals. $^{84}$

In addition, the instrumental effects of litigation on other areas of the climate change response, and their coherence both with other climate change policy instruments, and other elements of the climate change response, need to be identified and acknowledged. This is not the place for an exhaustive review of all areas where small scale litigation might constructively engage with climate change, and I appreciate that some of the points made may seem somewhat obscure in the abstract. Accordingly I shall make a few brief comments about technology transfer by way of illustration. An issue which has featured little in existing 'climate change litigation' is that of the access to and the transfer of technologies. Technology transfer has historically been something of a deadlocked issue in the international regime. ${ }^{85}$ However, the dissemination and use of technology has potential to support multiple initiatives that are crucial to the achievement of both mitigation and adaptation goals. Questions and disputes about technology present themselves as the minutiae within these broader areas of climate response: for instance, questions about the ownership of intellectual property rights in green or clean technology, the means to operate this technology, are all live and relevant climate change issues. Litigation about subsidies or incentives for renewable energy represent an intersection between multiple elements of climate change policy: technologies, finance, and specific mitigation commitments. ${ }^{86}$

Finally, it is arguable that one of the challenges confronting efforts at climate governance is a failure to approach all climate issues coherently, ensuring joined up thinking between different policy areas. It is quite conceivable, as actions are taken to meet the challenges climate change poses to society, that poor climate policy design or governance could not only achieve little, but effectively undermine other areas of climate response (or other important social or environmental issues). Similarly, as scholarship develops, progressively

\footnotetext{
${ }^{84}$ Acknowledging this would significantly change the profile of UK climate change litigation, as alluded to in the first section of this article.

85 Raymond Clémençon, 'The Bali Road Map' (2008) 17 The Journal of Environment \& Development 70: 'No fundamental breakthroughs can be accomplished on this topic. There is little that governments can do to force the private sector to share technologies with developing country counterparts, even if they wanted to, and the protection of intellectual property rights is a key concern of developed countries.', 82.

${ }^{86}$ See e.g. Breyer Group plc and others v Department of Energy and Climate Change [2015] EWCA Civ 408; [2015] WLR (D) 192. While of course, actions such as this may have little discernable impact in the sense of international technology transfer, they will undoubtedly impact on renewable energy use in the UK, undermining mitigation goals.
} 
clear distinctions are drawn between litigation 'about' mitigation or adaptation strategies. ${ }^{87}$ So for instance, there is potential for climate mitigation and adaptation strategies to overlap in dispute areas, for example, where new structures designed to mitigate fossil fuel use are not designed to take account of changing climatic conditions. This is probably best illustrated by an example. A raft of unintended consequences are known to occur in poorly executed energy efficiency works in buildings of cold countries, an essential part of many states' projected emissions reductions. One example is their tendency significantly to contribute to the severity of indoor overheating during hot weather. ${ }^{88}$ This will become progressively dangerous as the climate warms. ${ }^{89}$ Issues of poorly designed and enforced regulation aside, ${ }^{90}$ single-issue climate change litigation in relation to some aspect of this, could stand to undermine or undervalue any regulatory measures that have been taken in relation to different climate change issues that happened to interface with the same policy area. So extending the above example: litigation arising from overheating, an unintended consequence of energy efficiency works, could implicitly or explicitly challenge the reasonableness of design or construction decisions that do not take into account adaptation needs in the built environment. Used as a blunt instrument, such cases could deter energy efficiency installations, a crucial mitigation measure. ${ }^{91}$ For this reason, while I argue that our broadening of climate change litigation must include all issues relevant for a good climate change response, I would in addition argue that the need for policy coherence between different climate change areas is necessary too.

\subsection{Private Law}

Some might claim that public policy impacts are neither an obvious outcome nor the perceived chief purpose of private litigation, which in the main is designed for the resolution of self-contained disputes between private parties. ${ }^{92}$ It could be argued that administrative law and politics offer better and more legitimate avenues through which to affect social change or influence the operation of public bodies. Two responses follow. The first is, that

\footnotetext{
87 See Jacqueline Peel and Hari M Osofsky, Climate Change Litigation (Cambridge University Press 2015) Chapters 3 and 4.

$88 \mathrm{M}$ Davies and T Oreszczyn, 'The Unintended Consequences of Decarbonising the Built Environment: A UK Case Study' (2012) 46 Energy and Buildings 80; Anna Mavrogianni and others, 'Building Characteristics as Determinants of Propensity to High Indoor Summer Temperatures in London Dwellings' (2012) 55 Building and Environment 117. 89 CIBSE, 'Climate Change and the Indoor Environment: Impacts and Adaptation' (2005) TM36.

90 While there are regulatory measures designed to guard against this, they are both poorly designed and enforced, and crucially, do not adequately address the additional levels of risk which might be expected as the climate warms. In short, poor regulation in respect of a key climate change mitigation measures stands to undermine the need for appropriate adaptation measures in the same policy area.

91 This is to some extent an oversimplification; space does not permit a proper examination of the technical issues that would arise in such disputes. These will form the subject of future work.

92 Ernest Joseph Weinrib 'Understanding Private Law', The Idea of Private Law (Oxford University Press 2013).
} 
at this stage, only determined purists could deny that the outcomes and processes of private litigation carry implications that extend beyond discrete disputes. ${ }^{93}$ It is more broadly accepted that private liability makes a broad contribution in complex ways; there is a fairly substantial field of scholarship exploring the instrumental potential of private litigation. ${ }^{94}$ Even where a claimant or group of claimants have sought to advance their own interests through private litigation, in many instances they may well have or accept a broader social goal as well. The second response is: if we accept that private liability can have broader societal implications, then these may well materialise irrespective of whether they are actively pursued as a goal. This means that there must be inadvertent impacts of litigation either accepted or unanticipated by litigants.

Of course, determining the implications of private litigation is a complex and unpredictable process. While the field itself knows some controversy, it is probably not too difficult to accept that the effects of private liability claims can include the compensation for harm, punitive or deterrent effects on defendants, and the distribution of costs of accidents or other forms of wrongful and damaging behaviour. ${ }^{95}$ For these reasons it is both important and valuable to investigate how climate issues will be dealt with in private litigation, and to explore their potential impact on climate policy.

Accordingly, if we accept that both the absence or threat of liability risk can act as a pricing mechanism, ${ }^{96}$ shaping defendant behaviour either directly or through their insurers, then private liability claims in the climate change arena, acting as a form of regulation of private conduct, ${ }^{97}$ stand to shape climate regulation. This must include actions that resist litigation either for procedural reasons (for example, jurisdictional, standing or costs problems) or

\footnotetext{
93 Peter Cane 'Rights in Private Law' in Donal Nolan and Andrew Robertson (eds), Rights and Private Law (Hart Publishing 2011) describes this as 'fundamentalism'.

${ }^{94}$ For a comprehensive discussion, see Steve Hedley, 'Looking Outward or Looking Inward? Obligations Scholarship in the Early 21st Century' in Andrew Robertson and Hang Wu Tang (eds), The Goals of Private Law (Hart Publishing 2009) and the volume generally.

95 Glanville Williams, 'The Aims of the Law of Tort' (1951) 4 Current Legal Problems 137. Rich bodies of scholarship explore these possible functions in more depth. Similar arguments appear in tort scholarship, but also in the literature on governance and regulation, and discussions of tort and environmental law. Space does not permit a proper synthesis of these arguments, here, but particularly helpful and instructive scholarship may be found in Andrew Robertson and Tang Hang Wu, The Goals of Private Law (Andrew Robertson and Hang Wu Tang eds, Hart Publishing 2009); Maria Lee, 'Tort, Regulation and Environmental Liability' (2002) 22 Legal Studies 33; John Lowry and Rod Edmunds (eds), Environmental Protection and the Common Law (Hart 2000). A detailed and nuanced account of the interplay between private liability and insurance - in particular refuting the oft-held assumption that any instrumental potential of private law is absorbed by insurance: Rob Merkin and Jenny Steele Insurance and the Law of Obligations (OUP Oxford 2013).

${ }_{96}$ Classically, Richard A Posner, 'A Theory of Negligence' (1972) 1 The Journal of Legal Studies 29: “The dominant function of the fault system is to generate rules of liability that if followed will bring about, at least approximately, the efficient-the cost-justified-level of accidents and safety.", 33.

97 Peter Cane, 'Tort Law as Regulation' (2002) 31 Common Law World Review 305.
} 
substantive doctrinal reasons (for example, the absence of a duty of care). ${ }^{98}$ In these instances, the effect of the private liability is to create impunity for the harms caused; and particularly where no other remedy exists, this impunity would signal no deterrence or no restraint for the defendant. These decisions implicitly (or explicitly) locate the risk in relation to technologies or forms of enterprise; in addition, these can determine where the loss or risk of loss should fall in specific situations. ${ }^{99}$ And, this also cuts two ways. In as much as the risk of liability outcomes might shape norms or conduct, where there is no prospect of liability the defendant or persons in his position either evade enforcement or are not held to higher standards (depending on the purpose the litigation). ${ }^{100}$ The costs and risks occasioned by its conduct would remain where they had fallen.

The literature is already alive to the instrumental effect of litigation on some key climate change response areas. ${ }^{101}$ While simple deterrence or loss distribution undoubtedly does occur, this is the tip of the iceberg in terms of the complex and multiple impacts litigation might have in climate change cases. Each decision (or refusal to reach one) could have far reaching consequences both for parties to that discrete dispute, but also other similarly positioned companies or individuals; this determines how each should treat climate risks, the importance of mitigation measures, who bears the costs of climate damage, or how readily and transparently low carbon technologies should be transferred. I shall return to these points in more depth, later in the article.

Of course, while these outcomes might either discourage behaviour that undermines climate change (or the opposite) the regulatory role of liability risk is complex and is unlikely to be reducible to, say, simple deterrence or 'avoiding being sued', in every instance. For instance, the conduct and content of litigated disputes may play a role in defining or setting standards, and enforcing existing standards or rules. ${ }^{102}$ The impact of litigation also has potential to extend beyond the direct effect of liability findings to include the more subtle effects of judicial pronouncements, ${ }^{103}$ socio-technical advancements stimulated by the

\footnotetext{
98 Space does not permit a full discussion of this, but for example, the first wave of 'holy grail' cases discussed in Section 2.1 all failed on grounds of justiciability - see e.g. Comer v Murphy Oil USA, Inc 839 F. Supp. 2d 849, 855-62 (S.D. Miss. 2012). Of course, particularly smaller private disputes, which are less noticeable, are unlikely to encounter the kinds of justiciability problems that plagued the early 'holy grail' cases.

${ }_{99}$ This brief statement only scratches the surface on the deep analysis of the nuanced and complex interplay between different mechanisms for the allocation of risk in Merkin and Steele (n 95).

100 Cane, 'Tort Law as Regulation' (n 97) discusses these functions.

101 Peel and Osofsky (n 87).

102 This is one more instance of 'liability' acting as a form of regulation, see Cane, 'Tort Law as Regulation' (n 97) or shaping norms in a way that challenges or undermines more traditional forms of regulation - see Maria Lee, 'Safety, Regulation and Tort: Fault in Context' (2011) 74 The Modern Law Review 555.

103 Fisher (n 10).
} 
subject matter of the litigation, ${ }^{104}$ or even gradual awareness and developing values brought about by a 'radiating' effect of publicised private liability. ${ }^{105}$ Litigation about climate change informs public conceptions of it as both 'real' and serious. ${ }^{106}$ Or, as Weaver and Kysar explain: "Tort law enunciates general normative commands. These commands ultimately emerge from the nature of adjudication itself." ${ }^{107}$ For instance, the disclosure processes required as part of any hearing require production and scrutiny of industry or corporate materials, and financial information, that might otherwise be inaccessible. ${ }^{108}$ In addition, there is no prohibition on merits review within private litigation, and as such these disputes provide a forum for focused analysis of foreseeability, reasonableness, requirements of care, and characterisation of harm, and what these mean in a climate change context. This is not a simple or 'unidirectional' process, but litigation about climate change can inform social perceptions about the climate problem, which in turn feeds into judicial attitudes concerning the role of the courts in this context. ${ }^{109}$

\subsection{Invisibility and the Dangers of Climate Blind Litigation}

As I discussed earlier, for very obvious methodological reasons, some scholarship about climate change litigation tends to focus on cases that identify as such. ${ }^{110}$ However, there is potential for actions which somehow interface with some aspect of climate law or regulation, to be brought without a mention of climate change. This could be done for pragmatic, or of course, strategic reasons, or due to judicial refusal. ${ }^{111}$ There climate change would be an 'invisible issue' in the case, but for our contextual knowledge. While I make this as a general point, this is probably more marked in private law cases, because private law is designed around the litigants' opposing interests. ${ }^{112}$ And as I argue above, (private) litigation that somehow interfaces with climate change issues or policy will bear some impact, whether or

\footnotetext{
104 Preston (n 76) uses some examples of where this has occurred in the context of US atmospheric trust litigation. 105 Anne Bloom, 'The Radiating Effects of Torts' (2013) 62 DePaul Law Review 229.

106 Fisher (n 10), $242-3$.

107 Weaver and Kysar (n 36), 23.

${ }^{108}$ For instance, one might anticipate disclosure applications regarding the full extent of fossil fuel companies obfuscation tactics, in forthcoming 'carbon majors' litigation, see Frumhoff, Heede and Oreskes (n 44). The discovery process is ongoing in the Juliana litigation, as for instance: 'The discovery process in Juliana proved intriguing from the outset because of the status of the fossil-fuel industry as an intervenor-defendant party. This intervenor status subjected the industry to discovery requests [citation omitted] and created more opportunities for plaintiff attorneys to explore the longstanding, but largely surreptitious, relationship between the government and the fossil-fuel industry.' Blumm and Wood (n 83), 54.

109 Peel and Osofsky (n 87), Chapter 6.

110 Markell and Ruhl (n 4).

111 For likely strategic exclusion, see the long decision in In re Katrina Canal Breaches Consolidated Litigation (Robinson) 647 F. Supp. 2d 644 (E.D. La. 2009) (United States District Court, Eastern District of Louisiana). For refusal, see the discussion of climate protest prosecutions in Hilson (n 5) 'Reactive Litigation'.

112 See generally Peter Cane, The Anatomy of Tort Law (Hart Publishing 1997) or Peter Cane, Tort Law and Economic Interests (2nd ed, Clarendon Press 1996).
} 
not it is expressly delineated as climate change litigation, and whether or not all the climate pertinent issues are identified and explored. Now, there are strong reasons why such cases would be excluded from a categorisation or mapping approach to climate change litigation; not least, the multiplicity of actions that might engage with climate change in some respect are diverse and plentiful. ${ }^{113}$ And, in the early years of climate change litigation, it was entirely sensible to focus on actions that tackled the problem directly.

It might be more helpful, now, to conceive of (potentially all) litigation as happening in the context of climate change. ${ }^{114}$ This means it is time to look beyond actions that are overtly about climate change, and to pay attention to the multiple ways in which climate change issues might be present but invisible. Understanding climate change as a problem to be tackled on smaller scales as well, helps us to understand that the climate context has relevance in small or mundane disputes. ${ }^{115}$ Because private law litigation will shape behaviour, private law claims in the climate change context may well have some instrumental impact on domestic or international climate policy, whether or not this is done overtly, or the litigation categorised as 'climate litigation'. Yet conflicts will arise and be resolved in one manner or another, and where any aspect of said conflict interfaces with any element of climate change policy, could stand to reinforce or frustrate it.

For instance, private litigation about efficiency and pollutants from vehicles will have implications for emissions reduction strategy, as could professional negligence or product liability claims relating to energy efficiency or microgeneration in buildings. On one level, actions such as these are very much 'about' climate mitigation strategy, as they engage directly with policy measures designed to give effect, inter alia, to carbon reduction measures. However, claimants engaged in private litigation that interfaced with these areas would in all likelihood be motivated by their financial interests, not (or not only) by the need to reduce emissions. If the parties approach these solely as disputes about their private financial or property interests, there is potential for such cases to bear on climate change regulation and policy (even by changing the insurance or risk profile of the subject matter of

\footnotetext{
${ }^{113}$ For instance, Hilson (n 5) observes: 'However, while it may be relatively straightforward to decide what counts as litigation, it is more difficult to decide what counts as climate change litigation. The reason for this is because climate change is the consequence of billions of everyday human actions, personal, commercial and industrial. To that extent, virtually all litigation could be conceived of as [climate change litigation] CCL: after all, even the average contract dispute is likely to have a carbon implication somewhere within it if ones looks hard enough. However, that would of course make the identification and study of CCL extremely difficult: for that reason, CCL is taken in this chapter as requiring some sort of deliberate framing in climate change terms. In other words, litigation will amount to CCL if a climate change argument is explicitly presented as part of the claimant's or defendant's case.'

114 Bouwer (n 2).

${ }^{115}$ As I explain earlier, I focus here on private law for various reasons. However this is not solely a 'private law' argument.
} 
the litigation) in a way that is 'invisible'. Of course, it might not serve the parties to introduce climate change considerations into the litigation, or, it might not occur to them that the outcome of their dispute might have broader implications for climate policy. Indeed, it might not occur to anyone that the outcome of the dispute would have broader implications.

The above examples quite obviously relate to areas of climate change policy and regulation, and are fairly plainly related to domestic (or regional) measures that have been or should have been undertaken in the furtherance of mitigation or adaptation policy. It is also quite likely that a host of smaller, more mundane disputes that somehow interface with any aspects of global or domestic climate change policy are being litigated, but the broader context is not being acknowledged. ${ }^{116}$ For instance, disputes relating to insurance and risk, or intellectual property rights, could implicitly impact on accessibility of finance or new technologies to support climate change responses whether in the home jurisdiction or abroad.

As likely, are disputes or actions where 'invisible issues' appear unacknowledged alongside either implicit or explicit climate issues. The litigation process is frequently complex, detailed and lengthy and such a process would give rise to complex effects. Even in an explicitly framed climate case, there could be significant climate issues that are not aired or dealt with in a comprehensive or satisfactory manner. ${ }^{117}$ It would be nonsensical to require private parties to introduce climate change considerations into private litigation, particularly when this does not serve their interests, and of course this is not my suggestion. But this does raise broader questions as to who bears responsibility for identifying and acknowledging these issues, and at what stage.

I would argue, however, that where the resolution of disputes impacts on climate policy, it is better that it be done explicitly. The implications of this are that we need to recognise the relevance of even very small and mundane disputes, such as those between private parties

\footnotetext{
116 For instance, some of the cases referenced elsewhere in the article, which engage directly with aspects of climate change and energy policy (renewable energy and fracking), the climate change aspects remained largely invisible see Breyer (n 86) and Frackman (n 76).

117 Kim Bouwer, 'When Gist Is Mist: Mismatches in Small Scale Climate Change Litigation' [2015] Environmental Law and Management 11 - the harms occasioned by energy efficiency failures can never be accommodated within a tort claim. A further example relevant to energy efficienc measures: Most of this article was written prior to the Grenfell Tower tragedy, that devastated a block of low-cost housing and killed an as yet unknown number of people, in London on 14 June 2017. Now of course, nothing about Grenfell suggests a link to climate change. But, given that relatively cheap insulation materials appear to be implicated in difficulties extinguishing the blaze, related proceedings will make findings about energy efficiency materials and the compliance and enforcement of relevant provisions in Building Regulations. This means any proceedings are, potentially, climate change litigation as I conceptualise it in this article.
} 
or individuals, or of low financial value. Thus, even small and mundane issues may be categorised as climate change litigation, because of the impact (or lack thereof) that litigation outcomes would have on progressing climate goals. The very mundaneness or 'unsexiness' of many such matters, and the likelihood that the significance of these disputes could be missed entirely, make this additionally important. Importantly, this is not requiring permission for mundane small-scale actions to interact with higher levels of governance, and more an imperative that these multiple impacts be properly identified and analysed, as they will have an impact whether this is acknowledged, or not.

A failure to take account of both the blunt and radiating impact of the litigation and findings making it literally 'climate blind' litigation - means that the outcome will have some impact on climate change policy, but the action will be litigated without attention on these impacts. In contrast, a 'climate conscious' approach would include an awareness of where climate damage is invisible to self-interested parties, and when and in what circumstances liability outcomes have potential to determine climate change policy. ${ }^{118}$ While space does not permit a fuller discussion of this idea - which is in any event best illustrated by means of example underlying this idea is an appreciation that most legal doctrine could be subject to a range of acceptable interpretations. However it is arguable that this is not as simple as an either / or question. Because of the complexity of the climate change response, the subtle and deprioritised nature of some of the issues (for instance, negligible quantities of emissions) and a lack of joined up thinking, it is conceivable that even where the climate change context of the litigation is acknowledged - either in the proceedings by litigants or adjudicators or subsequently by commentators or analysts - some aspects of the litigation, such as what the remedies are directed towards, might still end up being climate blind. ${ }^{119}$ This is certainly not simple, and it is certainly not achievable when our conceptions of 'climate change litigation' still have an eye to the holy grail. However, noticing areas that are dealt with in an unsatisfactory (for climate change purposes) way in private litigation, is the first step towards ensuring their satisfactory management in other ways.

\section{Conclusion}

\footnotetext{
118 Space and the purpose of this article does not allow any substantial discussion of what I mean by 'climate blind' or 'climate conscious' approaches - this shall be left for later work. For instance, another kind of climate blind approach could include a narrow or rigid interpretation of the categories of interest protected in a private law claim. I should explain, in addition,, that I understand this to happen potentially during the progress of an action, by litigants or adjudicators, and subsequently by academics or commentators in analysing and reinterpreting the action. ${ }^{119}$ For instance, financially compensating a claimant for poor performance in an energy efficient building, without any measures to ameliorate the emissions implications of poor energy efficiency: Bouwer (n 117).
} 
I wrote this article in order to present some arguments about directions that might be taken in climate change litigation. I raise these arguments partly through an interest in the small scale of things, and partly to highlight the untapped potential in the field of climate change litigation. I also wished to emphasise that there are numerous actions that stand to reinforce or undermine aspects of climate change policy and regulation, and if this is to happen, it should happen overtly.

The work is important because the upswing of activity in the field of climate change litigation tends to focus on specific kinds of cases, and very broad aspects of climate policy. There is nothing wrong with this, other than where this approach is permitted to obscure the potential of alternative litigation about climate change. I raise a few points of focus that might support a more nuanced conception of climate change litigation.

In essence, I discuss four main features that support a new understanding of climate change litigation. First, there is limited scope in a continued preoccupation with large-scale climate cases as being definitive of the field. These cases have a role, and will continue to have a role; however, these are really the tip of the climate change litigation iceberg. That metaphor should provide sufficient caution with respect to ignoring the less visible or interesting issues that lie beneath. Second, relying on excellent overviews of climate change litigation, I noted that the vast majority of climate cases still centre around broad goals of emissions reduction. Of course, this is important, but there are many aspects of climate policy that may well provide fertile ground for different kinds of actions - or indeed, are already the site of ongoing climate actions - that remain underexplored.

Third, I argue that the role of private law in climate change litigation has been largely overlooked. With the exception of the classic group action in tort - the first wave of "holy grail' cases that I briefly touch on in Section 2.1., the potential of private law cases has been distinctly under-recognised. And fourth, I argue that the potential for invisibility of climate issues in (particularly) private litigation, reinforces the need for continual evaluation of the implications of climate cases.

I have argued that the field of climate change litigation is a complex and diverse field, and includes matters which lie in direct response to climate change regulation or policy, but also those that do not. I have also argued that, particularly in private law, it is not necessary for a dispute or action - or issues within or aspects of disputes or actions - to admit of climate 
ambitions, to have a role in climate policy. This is because the implications will be felt beyond the discrete litigation. However, the implications of numerous unacknowledged or undefined regulatory actions, in what is already a challenging policy area, are significant. For these reasons, I would suggest that a wider and more subtle understanding of 'climate change litigation' is fundamental for an adequately functioning climate policy.

These questions shift across scales by engaging local, or sometimes community measures, national, regional and international obligations and standards. They also require joined up thinking in terms of all aspects of a climate response. This, of course, is necessary from a policy level, but it is also necessary in relation to specific actions which challenge that policy: strategic litigation. Simply put, it is time to get down to the nitty-gritty. What is necessary, at domestic scales or lower, is very specific and focused litigation that challenges barriers to and supports the enablement of the promised contributions of state and non-state actors to the overall climate change response. Also, what is needed is some kind of sustained analysis - if not by litigants at the time, then by scholars subsequently - as to what the effect of these cases actually is. ${ }^{120}$ This requires increased specificity in relation to the policies and instruments that states themselves have identified as crucial in their own mitigation responses. However, in addition this requires renewed ambition and scrutiny in relation to all actions that might enable or hinder the progression of a safe and low-carbon pathway.

120 I am not suggesting that this is in any way being done in this paper. Here I make the case as to why this is necessary. 